Pesq. Vet. Bras. 36(7):617-624, julho 2016

DOI: $10.1590 / \mathrm{S} 0100-736 \mathrm{X} 2016000700010$

\title{
Role of the autologous mesenchymal stem cells compared with platelet rich plasma on cicatrization of cutaneous wounds in diabetic mice ${ }^{1}$
}

\author{
Napoleão M. Argolo Neto*, Ricardo J. Del Carlo ${ }^{3}$, Betânia S. Monteiro ${ }^{3}$, Nance B. Nardi ${ }^{4}$, \\ Pedro C. Chagastelles ${ }^{5}$, Ana Flora S. Brito ${ }^{3}$, Amanda M.S. Reis ${ }^{3}$ and Laís M.C. Silva ${ }^{2}$
}

\begin{abstract}
Argolo Neto N.M., Del Carlo R.J., Monteiro B.S., Nardi N.B., Chagastelles P.C., Brito A.F.S., Reis A.M.S. \& Silva L.M.C. 2016. Role of the autologous mesenchymal stem cells compared with platelet rich plasma on cicatrization of cutaneous wounds in diabetic mice. Pesquisa Veterinária Brasileira 36(7):617-624. Departamento de Clínica e Cirurgia Veterinária, Universidade Federal do Piauí, Campus Socopo, Teresina, PI 64049550, Brazil. E-mail: argolo_napoleao@ufpi.edu.br

Chronic cutaneous lesions affect $15 \%$ of diabetic human patients and represent a risk 15 to 46 times larger of limb amputations compared to people with normal glycemia. It is assumed that half of these amputations could be prevented by early treatment of wounds, for example, with proper cell therapy. Objectives: In this study, the action of the autologous transplant of mesenchymal stem-cells (MSC) was evaluated compared to the treatment with autologous platelet rich plasma (PRP) in the cicatrization of cutaneous lesions induced in diabetic mice. These animals were previously treated with streptozootocin to induce diabetes mellitus and round wounds of $1.5 \mathrm{~cm}$ in diameter were created in the posterior region. Diameters of the wounds and healing time were evaluated during 30 days and the results were submitted to variance analysis and Tukey's test average. It was noticed that the animals treated with MSC presented a more accelerated cicatrization of the cutaneous lesion than the animals treated with PRP. However, the treatment with PRP presented better results than just the daily asepsis of the lesions with saline or covering them with semi-permeable bandage. Besides, the use of semi-permeable bandage kept the cutaneous lesions of diabetic mice did not interfere negatively with cicatrization, proved to be harmless to use, but kept the cutaneous lesions more hydrated than the ones exposed to the environment.
\end{abstract}

INDEX TERMS: Cutaneous lesion, cicatrization, wound healing, mesenchymal stem cells, diabetes mellitus.

RESUMO.- [Papel das células-tronco mesenquimais autólogas em comparação com plasma rico em plaquetas na cicatrização de feridas cutâneas em camundongos

\footnotetext{
${ }^{1}$ Received on October 3, 2015.

Accepted for publication on February 10, 2016

2 Departmento de Clínica e Cirurgia Veterinária, Universidade Federal do Piauí (UFPI), Campus Socopo s/n, Teresina, PI 64049-550, Brazil. E-mail: laismeireles@live.com *Corresponding author: argolo_napoleao@ufpi.edu.br

${ }^{3}$ Departamento de Medicina Veterinária, Universidade Federal de Viçosa (UFV), Av. P.H. Ralfs s/n, Viçosa, MG 36570-900, Brazil. E-mails: ricarlo@ ufv.br, betania.monteiro@uvv.br, flora@hotmail.com,reis@hotmail.com

${ }^{4}$ Departamento de Medicina Veterinária, Universidade Luterana do Brasil (ULBRA), Rua João Goulart 666, Canoas, RS 76804-414, Brazil. E-mail: nardi@ufrgs.br

${ }^{5}$ Departamento de Medicina Veterinária, Universidade Federal do Rio Grande do Sul (UFRGS), Av. Paulo Gama 110, Porto Alegre, RS 90040-060, Brazil. E-mail: chagastelles@ufrgs.br
}

diabéticos.] Lesões cutâneas crônicas afetam 15\% dos pacientes diabéticos e humanos representam um risco 15 a 46 vezes maior de amputações de membros em comparação com as pessoas com a glicemia normal. Supõe-se que a metade destas amputações poderia ser evitada por meio do tratamento precoce das feridas cutâneas com, por exemplo, uma adequada terapia celular. Objetivos: Neste estudo, a ação do transplante autólogo de células estaminais mesenquimais (MSC) foi avaliada em comparação com o tratamento com plasma rico em plaquetas autólogo (PRP) na cicatrização de lesões cutâneas induzidas em camundongos diabéticos. Estes animais foram previamente tratados com estreptozotocina para induzir diabetes mellitus e feridas redondas de $1,5 \mathrm{~cm}$ de diâmetro foram criadas na região posterior. Os diâmetros dos ferimentos e tempo de cicatrização foram avaliados durante 30 dias e os resultados fo- 
ram submetidos à análise de variância e média pelo teste de Tukey. Verificou-se que os animais tratados com MSC apresentam uma cicatrização mais acelerada da lesão cutânea que do que os animais tratados com PRP. No entanto, o tratamento com PRP apresentou melhores resultados do que apenas a assepsia das lesões diariamente com solução salina ou cobrindo-os com atadura semi-permeável. Além disso, a utilização de atadura semi-permeável mantidas as lesões cutâneas de camundongos diabéticos não interfere negativamente com a cicatrização, provou ser inofensiva para usar, mas manteve as lesões cutâneas hidratadas mais do que os expostos ao meio ambiente.

TERMOS DE INDEXAÇÃO: Lesão cutânea, cicatrização da lesão, células-tronco mesenquimais, diabetes mellitus.

\section{INTRODUCTION}

Diabetes mellitus (DM) is a world health care problem. The chronic cutaneous lesions deriving from endothelial dysfunction, are one of the main complications of this disease and cause amputation in humans (Boyle et al. 2001, Avogaro et al. 2011, Adamo \& Caprio 2011).

Half of these amputations could be avoided through the early detection of diabetes and the appropriate treatment of cutaneous lesions, as cellular therapy and the use of somatic stem-cells (SSCs) (Tark et al. 2010, Altman et al. 2011) or platelet rich plasma (PRP) (Barbosa et al. 2008, Frykberg et al. 2010, Saad et al. 2011).

Mesenchymal stem-cells (MSC) are a type of SSCs easy to isolate and to culture from several organs, as they originate from mesodermal and non-mesodermal tissues and have a wide capacity of differentiation (Herzog et al. 2003, Meirelles et al. 2006, Altman et al. 2011).

The possibility to use autologous MSCs in the reparation of cutaneous lesions is an important therapeutic alternative, enabling diabetic or patients with cicatrization disorders be benefited (Bjornson et al. 1999, Shi et al. 2006, Tark et al. 2010). Contemporary research demonstrated the positive contribution of MSCs for the treatment of human skin lesions and to reduce the inflammatory phase of wound healing through, increased collagen deposition and the early phase of reepithelialization (Kim et al. 2011, Maharlooei et al. 2011).

In veterinary medicine, there is little research on the usage of autologous MSCs for skin healing in diabetic patients (Badillo et al. 2007, Falanga et al. 2007), a fact which underscores the need for standardization of methodologies used to study the clinical contribution of these cells in animal model of experimental diabetes.

PRP is widely used in tissue repair and promotes a strong cicatrization stimulus (Barbosa et al. 2008, Frykberg et al. 2010, Mehta et al. 2010). Until now, seven different growth factors (GF) present in the PRP were identified which significantly contribute to the cicatrization process. Besides, the PRP is a low cost and easy access product, excluding the need for special equipments (Barbosa et al. 2008, Saad et al. 2011).

The objective of this paper was to evaluate by means of clinical analysis the action of autologous mesenchymal stem-cells compared to the treatment with platelet rich plasma in the reparation of cutaneous lesions created in diabetic mice.

\section{MATERIAL AND METHODS}

Ethics statement. The methodology used in this study was approved by the Ethics Committee in Animal Experiments (CEEA) of the Federal University of Viçosa (UFV), according to the statement $n=43 / 2007$, in accordance to the regulations of the Brazilian Collegiate of Animal Experiment (COBEA).

Animals. Forty (40) male mice (Mus musculus, C57BL/6) were used, negative for the $g f p$ gene expression, average body weight of 30 grams and three weeks old. From those, 28 mice were used for clinical studies and 12 for the histopathological study. The mice were fed with commercial food for rodents and kept in individual cages, with controlled photoperiod, temperature and humidity for thirty consecutive days. The sample was calculated with confidence interval of $99 \%$ for sample calculation for finite populations (Triola, 1999). Also, five mice were used (Mus musculus) C57BL/6 as blood donors to obtain the PRP, not being used for the in vivo study.

Induction of type I diabetes mellitus. Intra-peritoneal injection of streptozootocin (Sigma Chemical Company, Saint Louis, USA), in the dose of $120 \mathrm{mg} / \mathrm{kg}$ (Delfino et al. 2002, Choi et al. 2003), diluted in $0.5 \mathrm{~mL}$ of sodium citrate buffer $0.01 \mathrm{M}, \mathrm{pH} 4.5$, in single dose was administered in all mice of this study.

Blood glucose was measured at fastening (Maharlooei et al. 2011), after seven days, in glucometer(Roche, São Paulo, Brazil). Animals that showed blood glucose values equal or superior to $250 \mathrm{mg} /$ dL (Carvalho et al. 2006; Volpato et al. 2006) and polydipsia were considered diabetic. Further, blood glucose was measured in the morning, non fastening, until the end of the experiment (30 days).

Based on results of a pilot study, after seven days, treatment for diabetes was started with isophane human insulin (Novo Nordisk Farmacêutica do Brazil Ltda, São Paulo, Brazil), subcutaneously, on the dosage of $20 \mathrm{U} / \mathrm{Kg}$ or $6 \mathrm{U} /$ mice, adjusted according to the individual blood glucose, to prevent the blood glucose exceed $300 \mathrm{mg} / \mathrm{dL}$, which lead to their death.

Mesenchymal stem-cell cultures. Mesenchymal stem cells (MSC) were collected by the Immunogenetics Laboratory of the Federal University of Rio Grande do Sul, from the bone marrow of isogenic C57BL/ 6 mice, positive for the expression of gene $g f p$ and donated to this search.

These cells were centrifuged at a temperature of $22^{\circ} \mathrm{C}$ and $1500 \mathrm{rpm}$ for 10 minutes. The supernatant was discarded and pellet resuspended in $0.5 \mathrm{~mL}$ of culture media (Sigma Chemical Company, Saint Louis, USA). From this solution, an aliquot was removed, diluted in Trypan Blue (1:1), for cell count in Neubauer chamber.

When the minimum cell concentration of $5 \times 10^{6}$ cells $/ \mathrm{mL}$ was obtained, cells were incubated at $37^{\circ} \mathrm{C}$ in $5 \%$ of $\mathrm{CO}_{2}$ and air humidity of $95 \%$, and the culture media were weekly changed until the formation of a cell monolayer.

Later, the culture media were discarded and the cells of the monolayer were washed with buffered phosphate saline solution (PBS), pH 7.2, pre-heated at $37^{\circ} \mathrm{C}$ and trypsinized ( $1 \mathrm{~mL}$ of trypsin $0.25 \%$ ) (Sigma Chemical Company, Saint Louis, USA). Trypsin was inactivated with the addition of PBS, the solution was centrifuged and the supernatant was discarded. Cells were resuspended with $3.5 \mathrm{~mL}$ of culture media and transferred into culture flasks of $25 \mathrm{~cm}^{2}$, which were kept incubated at $37^{\circ} \mathrm{C}$ and $5 \%$ of $\mathrm{CO}_{2}$.

The culture media of the flasks were changed every four days, and when the cells confluence of $80 \%$ were obtained, cells were washed, trypsinized, transferred into flasks with the double of original area $(1: 2)$ and kept incubated at $37^{\circ} \mathrm{C}$ and $5 \%$ of $\mathrm{CO}_{2}$. 
When the minimum cell concentration of $3 \times 10^{7}$ cells $/ \mathrm{mL}$, the solution with suspended MSC in PBS was transported on microtubules for the surgical site, for immediate transplantation in C57BL6 mice.

Fluorescence-activated cell sorting (FACS). Cells were trypsinized, collected and incubated for 30 minutes at $4^{\circ} \mathrm{C}$ with phycoerythrin (PE)- or fluorescein isothicyanate (FITC)- conjugated antibodies against murine CD45, CD11b, CD90.2, CD49e, CD29 and CD44. Excess antibody was removed by washing. Detection of PE and FITC staining was accomplished on a FACS can cytometer (Kim et al. 2011, Nardi \& Meirelles 2006).

Blood collection to obtain PRP. The blood donor mice were anesthetized (Crisfarma Ltda, Aracaju, Brazil.) and the left ventricle punctured for the collection of all circulating blood. The blood sample was centrifuged with anti-coagulant (Quibasa Química Básica Ltda, Belo Horizonte, Brazil) during 5 minutes, at a speed of $1500 \mathrm{rpm}$ at $4^{\circ} \mathrm{C}$ resulting in the two following layers: the inferior layer composed of red cells and the superior layer made up of plasma. The plasma layer was first aspirated to avoid its mixing up with the erythrocytes and was centrifuged for another 5 minutes at $1500 \mathrm{rpm}$ in order to separate a few erythrocytes still present. The total plasma volume was counted and distributed into tubes containing $50 \mu \mathrm{L}$ of plasma added $25 \mu \mathrm{L}$ of $10 \%$ calcium gluconate for activation and placed in bain-marie at $37^{\circ} \mathrm{C}$ until plasma gelation (Tark et al. 2010; Saad et al, 2011, Frykberg et al. 2010). The plasma preparation took place moments before the application.

Origin of cutaneous wounds. Two week after inducing DM, animals were anesthetized by peritoneal application ketamine $0.02 \mathrm{~mL} / 100 \mathrm{~g}$ (Fort Dodge Saúde Animal, Campinas, Brazil) and xylazine $0.0015 \mathrm{~mL} / 100 \mathrm{~g}$ (Virbac Saúde Animal, São Paulo, Brazil) used in combination and trichotomized in the dorsal region and were submitted to antimicrobial (Bayer ${ }^{\circledR}$ Saúde Animal, São Paulo, Brazil) and analgesic therapeutics (Cristália Produtos Químicos Farmacêuticos Ltda Itapira, Brazil) before the surgical procedure.

Antisepsis of the trichotomized area was performed, and a round wound of $1.5 \mathrm{~cm}$ of diameter was created, by removing skin of the animal with a punch. However, based on the results of a pilot study, which identified that the retraction of the wound edges influenced the lesion areas, they were sutured to the surrounding muscle with a nylon monofilament thread, in simple separated stitches.

Treatments. The 40 mice were randomly separated into four groups of ten subjects each. The time it took to obtain the MSC solution in the concentration of $3.3 \times 10^{7}$ cells $/ \mathrm{mL}$ and the PRP in the concentration of $2 \times 10^{7}$ platelets $/ \mu \mathrm{L}$ to the transplant for the cutaneous lesions in the mice was 30 minutes. All mice were treated immediately after surgical procedure and observed daily for 30 consecutive days.

The witness group (WG) was constituted of mice in which the cutaneous lesions were treated with saline. In the mesenchymal stem-cell (GSC) and platelet rich plasma (GPR) groups, were treated with the MSC and platelet rich plasma, autologous, respectively, in one application, covered with a semi-permeable adherent polyurethane membrane (3M Nexcare Company, Saint Paul, USA) used to keep the MSC and PRP in the location of the lesion. In the polyurethane group (PG) the cutaneous lesions were covered with a semi-permeable adherent polyurethane membrane.

The polyurethane membranes are permeable to gases and impermeable to liquids, keeping local humidity. After 48 hours of the surgical procedure, the cutaneous lesions of all the mice were cleaned, daily, with saline moist gauze and the polyurethane membranes were replaced.

Clinical evaluation. In all the mice the following was evaluated: weight, hydric ingestion, glycemia, food intake and the cutaneous lesions were inspected, once a day during the experiment.
The variables lesion areas (LA) and cicatrization time (CT) were analyzed daily be means of digital photographs with standardized light intensity and camera height. The images were transferred and evaluated in a computerized analysis program (Softium Informática Ltda, Fortaleza, Brazil).

For each mouse the average was obtained of the values found for the LA and CT variables. From the average of each variable for each mouse of the corresponding group, the group averages were obtained.

Biopsy and histological procedures. On the 12 th day of treatment, three animals of each group were randomly selected, weighed and submitted to euthanasia for anesthetic overdose with Isoflurane. An incisional biopsy was performed, with excision of the entire wound and a margin of intact skin.

Skin samples were fixed in buffered paraformaldehyde at $10 \%$ for 24 hours and dehydrated in solutions of increasing concentrations of ethanol, cleared in xylene, included in histological paraffin and sectioned with a rotary microtome, adjusted to $4 \mu \mathrm{m}$ thick. Slices were fixed in glass slide and stained by picrosirius (Sirius red and picric acid), for identification and quantification of type I and type III collagen fibers.

Later, a mouse of the GSC was also weighed and submitted to euthanasia, after the complete cicatrization of the cutaneous lesion. The skin sample received the same histological procedure and was inserted in histological wax, with the objective of preserving the material for future analysis of the polymerase chain reaction (PCR).

Colagen fiber evaluation. The hystological slices stained by the picrosirius method were observed in polarized light microscope conected to a microcomputer equipped with software for image capture (Diagnostic Instruments Inc, Sterling Heights, USA).

To assess the variable collagen fibers (COF), three images from different sites of each part of the hystological slices were recorded, using objective of $10 \mathrm{X}$ with zoom of 1.5 and MAG of $37.5 \%$. After captured, the images were analyzed by a image analysis program (ImageLab Pro Plus v.4.5, Silver Spring, USA), with the aim of assessing the ratio of type I and type III collagen fibers. For such, a grid with 50 intersections on the image analyzed was used, and the dots over orange or yellow collors were counted to quantify type I collagen fibers, green to quantify the type III collagen fibers, and black to identify regions were no fiber was found. The percentage of each color was established, for each individually hystological slice and, from these, the means of groups was obtained.

DNA extraction. The genomic DNA extraction of the primary culture of MSC positive for presence of the gene $g f p$ (positive control) was performed, from fresh bone tissue of C57BL6 mouse isogenic from those used (negative control) and paraffin embedded sample of the animal of group CG, as per protocol of the kit (Qiagen, São Paulo, Brazil). The sample embedded in paraffin was deparaffinized and rehydrated previous to the steps of DNA extraction.

Polimerase Chain Reaction (PCR). For identification of the gene $g f p$ in the cutaneous tissue biopsy of the MSC-treated animal, PCR in the DNA extracted from the biopsy was performed. For such, the enlargement of a fragment of 225 base pairs (bp) was performed of the gene $g f p$ using primers: gfp-5C 5' ACT TCA AGA TCC GCC ACA ACA T 3' (direct) and gfp-3C 5' TTA CTT GTA CAG CTC GTC CAT GC 3' (reverse), with the aim of verifying the presence of the gfp gene in tissue samples. The reaction was developed in a final volume of $25.0 \mu \mathrm{L}$ with the following reagents: $7.0 \mu \mathrm{L}$ of DNA of the sample; $2.5 \mu \mathrm{L}$ of primer $g f p-5 \mathrm{C}$ to $0.02 \mathrm{mM}$; $2.5 \mu \mathrm{L}$ of primer $g f p-3 \mathrm{C}$ to $0.02 \mathrm{mM} ; 2.5 \mu \mathrm{L}$ of each dNTP to $2.0 \mathrm{mM}$ (dATP, dTTP, dGTP, dCTP); $2.5 \mu \mathrm{L}$ of buffer of Taq DNA polymerase $1 \mathrm{x}$ and $1 \mathrm{U}$ of Taq DNA polymerase (Invitrogen Co, Carlsbad, USA).

PCR was performed with a stage of initial denaturing at $94^{\circ} \mathrm{C}$ for 5 minutes, followed by cycles of three steps: denaturing at $94^{\circ} \mathrm{C}$ 
for 35 seconds, annealing at $58^{\circ} \mathrm{C}$ for 45 seconds and extension at $72^{\circ} \mathrm{C}$ for 1 minute, in a total of 40 cycles. A final extension step was performed at $72^{\circ} \mathrm{C}$ for 7 minutes. The PCR products were analysed by $1.5 \%$ polyacrylamide gel electrophoresis, and stained in solution of ethidium bromide for visualization in transluminator.

Sequencing reaction of PCR product. After confirmation by electrophoresis of the enlargement of fragment of gene $g f p$, the enlarged material was purified (USB Corporation, Cleveland, USA).

After purification, samples were submitted to sequencing using the DNA sequencer (model ABI Prism 3100 Genetic Analyser - Applied Biosystems, Perkin Elmer, USA) and "Kit Big Dye 3.1". Obtained sequences were analysed in sillico by program BLAST ${ }^{\circledR}$ to determine the similarity with other corresponding sequences of the gene $g f p$ deposited in the GenBank databank.

Statistical analysis. The results were analyzed with the aid of specific software (Sistema para Análises Estatísticas ${ }^{\circledR}$ v.9.1 UFV, Viçosa, Brazil), submitted to the Kolmogorov-Smirnov test for verification of normality distribution of the variables LA, CT and COF.
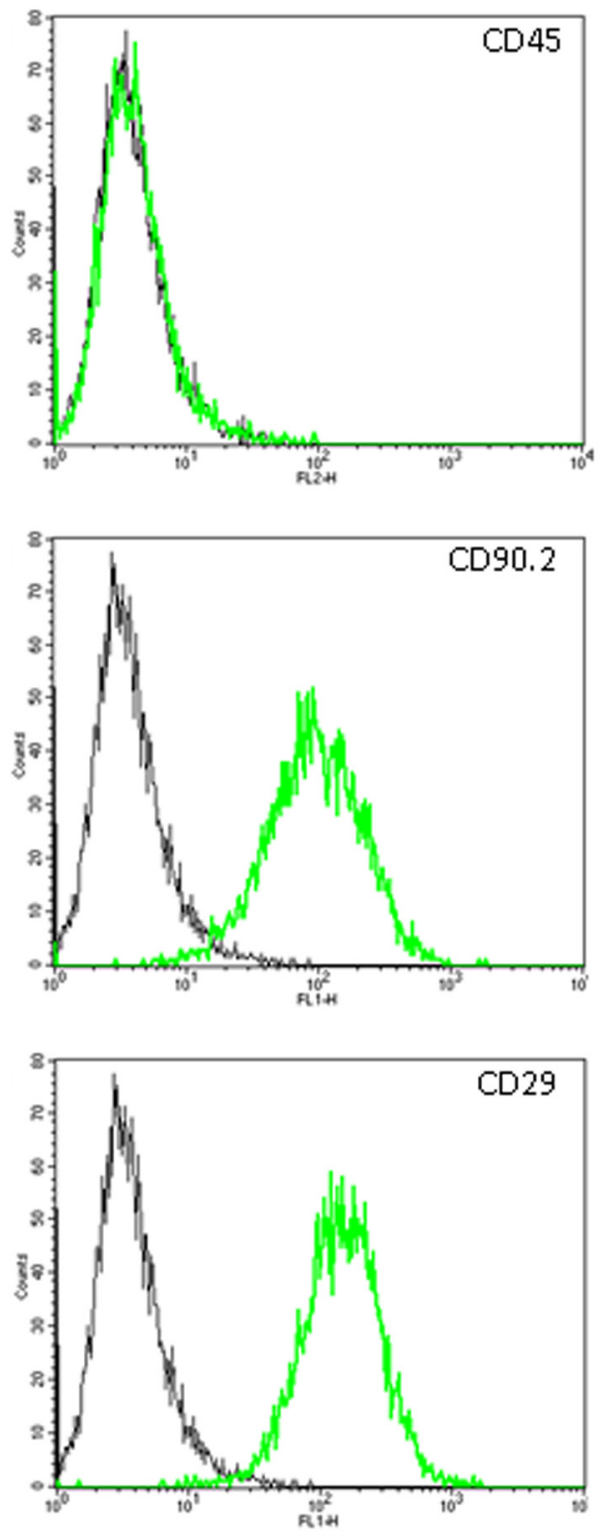

Since the variables presented normal distribution, a variance analysis was made (ANOVA) for LA, CT and COF seeking the identification of differences between the independent groups. When the treatment effect was detected a post hoc comparison test was made of Tuckey averages. For the LA variables also a regression analysis to evaluate the evolution between the studied groups was made.

A level of rejection of the nullity hypothesis of $1 \%(\mathrm{p} \leq 0.01)$ for both analyses.

\section{RESULTS}

The MSC cultivated were flat, fibroblasts-like and plastic-aderent. These cells were positive for CD90.2, CD49e, CD29 and CD44, and negative for CD45 and CD11b (Fig.1).

Differences were seen $(\mathrm{p}<0.01)$ among the treated groups, for the LA and CT variables (Table 1). The mice treated with MSC presented the lower averages for the variables LA and CT, when compared to the other treatments.
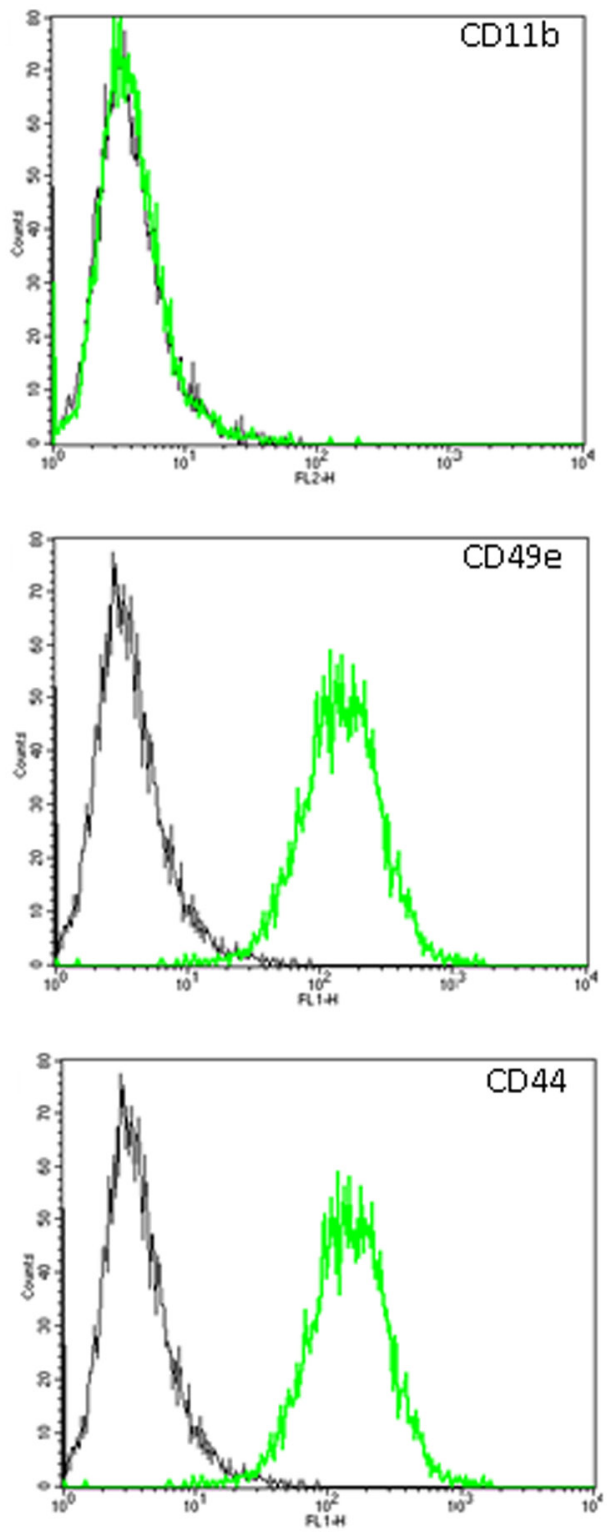

Fig.1. Expression of surface markers by murine MSC. Histograms demonstrating the expression of the indicated surface molecules (green lines) are plotted against controls (black lines). 
The group treated with PRP presented average values for these variables superior to the GSC group and inferior to the WG and PG. The group treated with the semi-permeable adherent polyurethane membrane presented average intermediary values for these variables and the WG presented the higher values (Table 1).

In the evaluation of the time influence for the complete cicatrization of the lesions, a difference was seen $(p<0,01)$ between the studied groups, having an accentuated tendency for null values that represent a complete cicatrization

Table 1. Average of the values found for the LA, CT variables, type I and type III collagen in mice C57BL6 $(\mathrm{n}=28)$ submitted to saline treatment, autologous mesenchymal stem cell transplant, topical application of autologous platelet rich plasma and covering of the lesions with semi-permeable adherent membrane, respectively for 30 consecutive days

\begin{tabular}{lcccc}
\hline Groups & $\begin{array}{c}\text { Mean lesion } \\
\text { area, cm }\end{array}$ & $\begin{array}{c}\text { Mean } \\
\text { CT, days }\end{array}$ & $\begin{array}{c}\text { Mean type I } \\
\text { collagen,\% } \%\end{array}$ & $\begin{array}{c}\text { Mean type III } \\
\text { collagen, \% }\end{array}$ \\
\hline $\begin{array}{l}\text { Witness group } \\
\text { MSC }\end{array}$ & $0,6902^{\mathrm{a}}$ & $26,8571^{\mathrm{a}}$ & $34,67^{\mathrm{a}}$ & $16,50^{\mathrm{a}}$ \\
$\begin{array}{l}\text { Autologous platelet } \\
\text { rich plasma }\end{array}$ & $0,2722^{\mathrm{b}}$ & $14,7143^{\mathrm{b}}$ & $45,50^{\mathrm{b}}$ & $22,34^{\mathrm{b}}$ \\
Membrane & $0,340^{\mathrm{bc}}$ & $16,8571^{\mathrm{bc}}$ & $40,34^{\mathrm{c}}$ & $20,00^{\mathrm{c}}$ \\
Polnu & $0,3829^{\mathrm{c}}$ & $18,2857^{\mathrm{c}}$ & $37,67^{\mathrm{a}}$ & $18,67^{\mathrm{a}}$
\end{tabular}

Polyurethane

Values followed by different letters have significative difference to each other. Tukey test - $1 \%$ significance.

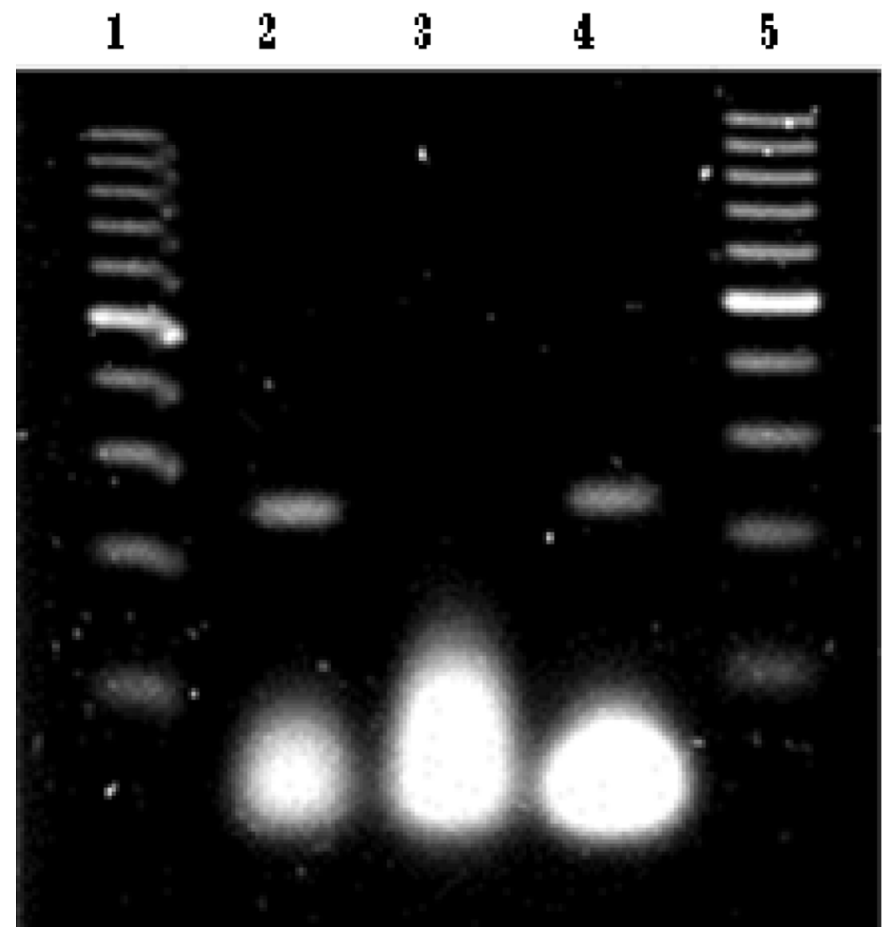

Fig.2. Photograph of the agarose gel showing the band of the samples submitted to PCR. The channel 1 and 5 contain a standard marker of 100 pair-bases. Channel 2 contains the product of the PCR and MSC in culture (positive control). Channel 3 containing the product of PCR of the cutaneous tissue sample of the mice that was not treated with MSC (negative control). Channel 4 containing the product of the PCR of the waxed cutaneous tissue sample of mice treated with MSC, demonstrating the identification of the presence of infused GFP-positive stem cells, in the skin tissue of treated mice.

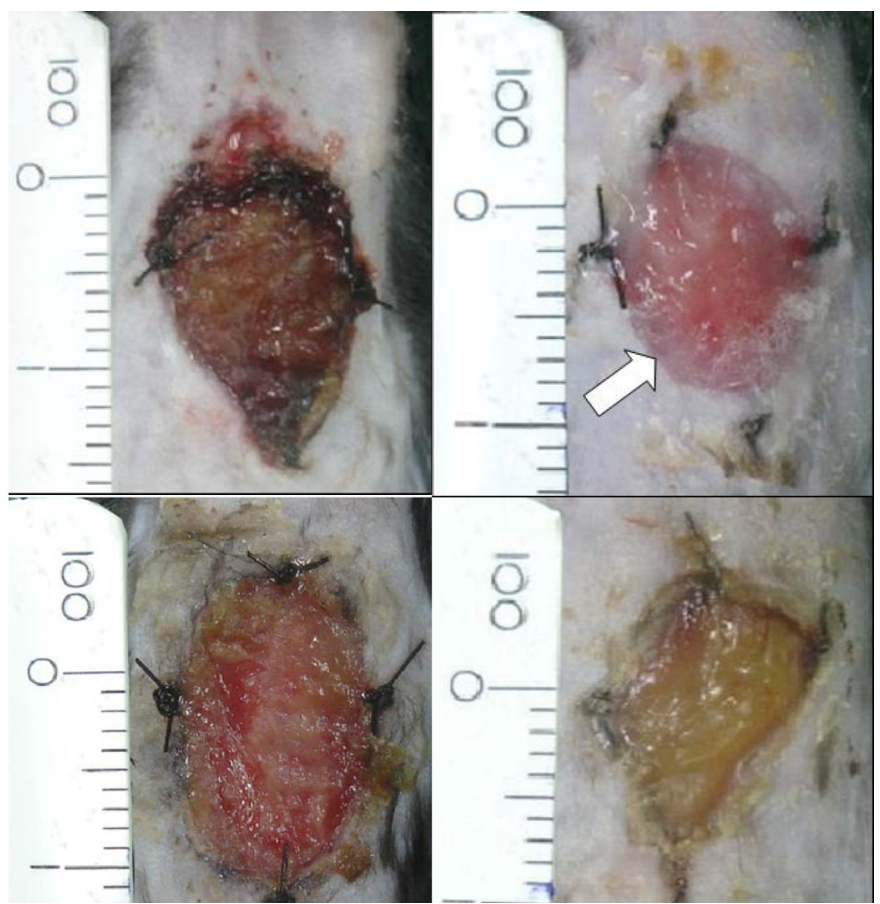

Fig.3. Experimental cutaneous lesions in mice C57BL6 with eight days of clinical evolution. A: lesion dried and erythematous-crusted treated with daily asepsis of saline. B: humid lesion, non-exsudative and with marginal re-epithelization starting from the edges of the lesions (white arrow), treated with autologous transplant of MSC. C: humid lesion, non-exsudative, with evident formation of granulation tissue (irregular surface - blue arrow), treated with autologous PRP. D: humid lesion, non-exsudative and with the accumulation of fibrinoid material, treated with the covering of the lesion with semi-permeable adherent polyurethane membrane.

of the lesion, in the mice of GSC, followed by the GPR, in relation to the other groups. The mathematical cubic regression model justify the data, as represented in chart 1 (a, b, c, d), with its respective adjusted determination coefficients.

Differences were seen $(p<0,01)$ between the treated groups, for the average percentage of type I and type III collagen fibers (Table 1). Between the mice treated with MSC higher averages for the type I and type III collagen fibers percentage was seen, followed by the mice treated with PRP, when compared to the other treatments. The group treated with the semi-permeable adherent polyurerethane membrane presented average intermediary values and the witness group, the highest values (Table 1).

The PCR technique identified a band of the $g f p$ reporter gene in the agarose gel of the mouse treated with MSC, similar to the positive control, close to $225 \mathrm{pb}$ (Fig.2).

Twenty nine mice presented glycemic level higher than $250 \mathrm{mg} / \mathrm{dL}$ seven days after the application of the streptozootocin (STZ) solution and 11 mice presented seven days after the second application of STZ. The average glycemic levels of the mice increased gradually, for twelve consecutive days, starting from the first measurement (Chart 2). Even after the start of the treatment with human isophane insulin, the post-prandial glycemia remained above $250 \mathrm{mg} / \mathrm{dL}$. 
The visual inspection of the lesions, the mice of the witness group presented dried lesions and erythematous-crusted that regressed slowly until the loss of the superficial crust and epithelization. The lesions from the polyurethane group presented themselves humid and non-exudative, with a discreet accumulation of fibroid material. The mice in the GPR group presented humid and non-exudative lesions, with an evident formation of granulation tissue. The lesion treated with MSC presented themselves humid, non-exudative and with marginal epithelization from the edges of the lesion (Fig.3).

\section{DISCUSSION}

There are few available studies using autologous MSC and PRP in animals. Because DM changes the expression of cytokines (Buschard 2011, Hughson et al. 2011, Jiang et al. 2011, Touvra et al. 2011), there remain large uncertainties of cellular components of the diabetic patient will respond successfully to stimulate the skin heals.

The authors of this paper chose not to measure growth factors in autologous PRP before and after induction of diabetes, due to the unpredictability of the transplantation of autologous MSC and PRP of animals diabetics for skin healing. Therefore, this study evaluated the clinical effect of this therapy in cutaneous wound healing in diabetic mice model. Later, we intend to deepen this study, measuring microcirculatory changes due to diabetes in this animal model and variations in the concentrations of growth factors in autologous PRP and the injury site before and after induction of diabetes.

The characteristic morphology and the molecular level by flow cytometry of MSC cultivated in this study was the same described by other studies for identifying murine MSC (Badillo et al. 2007, Falanga et al. 2007, Inoue et al. 2008, Kwon et al. 2008, Mehta et al. 2010, Jiang et al. 2011, Kim et al. 2011).

Even though the submitted to the same deletary effects of hyperglycemia, the mice treated with MSC presented inferior average values of the lesion area $(p<0,01)$ in relation to the other treatment. Previous research has shown that hyperglycemia induces a state of mild chronic inflammation, which interferes with the balance of the production of cytokines involved in tissue repair (Hughson et al. 2011, Jiang et al. 2011). The more intense cicatrization observed in the lesions of this group can be attributed to the immunomodulation characteristics and plasticity of the MSC.

The molecular mechanism involved in the immunomodulatory properties of the MSC have not been completely elucidated, but it is known that these cells produce a great number of soluble factors that interfere in the behavior of inflammatory cells (Nauta \& Fibbe 2007, Del Carlo et al. 2009). One of the main anti-inflammatory soluble factors produced by the MSC is the indoleamine 2,3-dioxygenase (IDO) (Kim et al. 2011, Inoue et al. 2008). It is possible that the used MSC in this study have contributed positively in the reduction of the inflammatory phase of cicatrization in mice of the GSC by means of the IDO secretion.

Besides, of all the adult stem-cell lineages studied to the present moment the MSC presented higher plasticity, originating mesodermal and non-mesodermal tissues (Verfaillie 2002, Meirelles et al. 2006). For this reason the MSC used in the lesions of the mice from group GSC can have originated or stimulated the differentiation of cellular type committed with cicatrization, such as fibroblasts, increasing deposition of collagen in the lesion bed.

Corroborating this hypothesis, the mice treated with MSC presented average percentage values of type I and type III collagens superior to $(p<0,01)$ the other treatments (Table 1). The higher percentage of collagen in the lesions of mice from the group GSC indicates intense fibroblastic action, seen that these are one the most responsible cells for the replacement of are the fibronectin and proteoglycan of the extra cellular matrix per collagen, main component of the scar in formation (Balbino et al. 2005). Besides, according to contemporary studies (Jiang et al. 2011, Kim et al. 2011), indicate that the cutaneous lesions of the mice in group GSC are in an advanced cicatrization stage, characterized by the formation of stronger and elastic connective tissue.

The predominance of the type I collagen over the type III, observed in groups WG, GSC, GPR and PG (Table 1) was expected, because these collagens are present in the healthy dermis and represent approximately $87 \%$ and $10 \%$, respectively of the dermal collagen in animals (Kim et al. 2011, Maharlooei et al. 2011).

However, it was not possible to elucidate if the fibroblasts responsible for the increase in collagen percentage in mice lesions from group GSC originated from the transplanted autologous MSC or just stimulated by them.

The identification of the $g f p$ gene of the MSC in the cicatrizated cutaneous tissue in the mice of the GSC group by the PCR technique (Fig.2) indicates that the MSC were present in the tissue, differentiated or not. However, as only one animal was evaluated, further studies are needed to identify whether all the transplanted MSC persist in all scar tissue.

The mice treated with an autologous MSC transplant have also presented a decrease $(\mathrm{p}<0.01)$ in the average values for the CT variable, when compared to the other treatment (Table 1). In the same manner, probably, happen for the LA variable, the decrease in cicatrization time can also be explained by immunomodulation and plasticity. Besides, the accentuated fibroplasty, identified for the increase in concentration of collagen at the location, contributed for the reduction in cicatrization time between the mice treated with MSC.

A positive influence was seen $(\mathrm{p}<0.01)$ of time in the decrease of the lesion area between the studied groups, having accentuated tendency to early cicatrization among the mice from the GSC group, followed by the groups GPR, PG and WG (Chart 1a, 1b, 1c, 1d).

The mice treated with PRP presented average values of the lesion area and cicatrization time inferior $(\mathrm{p}<0,01)$ to the mice of groups WG and PG (Table 1). How diabetes leads to reduced serum levels of growth factors pro-healing (25), it is believed that the platelet-rich plasma used in this study has contributed to these growth factors, justifying the results.

The PRP is described as rich in pro-cicatrization FC 
(Frykberg et al. 2010, Saad et al. 2011) and it is believed that in this study, the transplanted platelets for the cutaneous lesions of the mice have been activated by the contact with the sub-endothelial collagen exposed in the lesions and have released the GF present in the alpha granules. These GF have probably contributed positively for the cicatrization of the lesion in mice of the GPR group. This mechanism has already been described before by other authors (Barbosa et al. 2008, Frykberg et al. 2010, Jiang et al. 2011, Touvra et al. 2011) and it is believed that it occurs similarly in animals.

Likewise the mice treated with MSC, the GPR group presented average percentage values of type I and type III collagens superior $(p<0.01)$ to the treatments with an adherent polyurethane membrane and asepsis of the lesions with saline (Table 1), indicating greater fibroblastic activity and formation of stronger and more elastic connective tissue (Tark et al. 2010, Jiang et al. 2011).

This acceleration of the cicatrization of cutaneous lesion treated with PRP has already been reported in human, rabbits and horses (Derossi et al. 2009, Frykberg et al. 2010, Vendramim et al. 2010, Saad et al. 2011) corroborating with the results of the present study.

However, a positive contribution $(\mathrm{p}<0.01)$ in the treatment of lesions of the mice in group GPR was not seen, when compared to the GSC. This is possibly due to the elevated plasticity of the MSC, beside its capacity of secreting pro-cicatrization $\mathrm{FC}$, which supplemented the benefit give by the PRP treatment in this study.

The PG group presented averages for the LA and TC (Table 1) variables, inferior $(p<0.01)$ to the WG group. These adherent bandages kept the humidity in the lesion bed, enabling the cellular migration of the edges in the center of the lesion, observed in the same way by other authors (Chiari et al. 1988, Mandelbaum et al. 2003). This characteristic probably favored the action of miofibroblasts in the lesion edges and contributed for the acceleration of the turnover of inflammatory cells, events that favor the tissue reparation. Besides, the maintenance of hydration of the lesion tissue prevented the tissue dissection and avoided the formation of crusts.

However, no differences were identified $(p<0.01)$ between the mice from groups PG and WG regarding the percentage of type I and type III collagens, demonstrating that the semi-permeable adherent polyurethane membrane does not stimulate tissue fibroplasias (Table 1).

The benefits in using the polyurethane membrane seem to be related to the mechanical effect of humidity maintenance in the lesion bed and the MSC in the location. In relation to the first, previous studies (Chiari et al. 1988, Grossi 1998) related the positive contribution of several semi-permeable adherent bandages, accelerating in almost two times the cutaneous cicatrization process in relation to the lesions exposed to the environment.

Also, the mice of the GSC have benefited from the maintenance of humidity in the lesion bed, once that he lower values found for the variable LA and TC, when compared to the groups GPR, PG and WG, show that the MSC found an adequate environment for it development.
The persistent fasting hyperglycemia associated to the manifestation of emaciation and polidipsia, proves the induction of DM, which experimental model has already been successfully described in rats, mice and dogs (Volpato et al. 2006, Inoue et al. 2008, Kwon et al. 2008, Buschard 2011, Maharlooei et al. 2011). The persistance of hyperglycemia, during the insulin treatment, observed in the present study, was also described in recent researches (Delfino et al. 2002, Spadella et al. 2005).

Furthermore, the hyperglycemia could have been the responsible for the higher values found for the LA variables between the mice in the witness and polyurethane groups (Table 1), since it is incriminated as the main responsible for the chronicity of cutaneous lesions in diabetic humans and rodents treated with STZ (Volpato et al. 2006, Inoue et al. 2008, Kwon et al. 2008, Buschard 2011, Maharlooei et al. 2011).

\section{CONCLUSIONS}

It could be concluded that the autologous transplant of MSC had a greater positive effect on wound healing, than the topical treatment with PRP.

The topical treatment with PRP stimulates the cicatrization in cutaneous lesions in a more efficient way than the daily asepsis of cutaneous lesions with saline.

Statistically significant results were noted for both treatments, on the wound size change, cicatrization time and quantification of type I and type III collagen fibers, compared with the control group.

The semi-permeable adherent bandage did not interfere with collagen production, proved to be harmless to use, but kept the cutaneous lesions more hydrated than the ones exposed to the environment.

From these results, further studies are needed to quantify the growth factors in autologous platelet-rich plasma and to identify all the MSC transplanted persist in the scar tissue.

Acknowledgments.- The authors are grateful to the Foundation of the State of Minas Gerais Research (FAPEMIG); to Commission of Higher Education Personnel Improvement Technique (CAPES); to National Council for Scientific and Technological Development (CNPq), and to Prof. Joaquin Hernán Patarroyo Salcedo/BIOAGRO/ UFV for valuable technical support.

Conflict of interest statement.- The authors have no competing interests.

\section{REFERENCES}

Adamo E. \& Caprio S. 2011. Type 2 diabetes in youth: epidemiology and pathophysiology. Diabetes Care 34(2):161-165.

Altman A.M., Prantl L., Muehlberg F.L., Song Y.H., Seidensticker M., Butler C.E. \& Alt E.U. 2011. Wound microenvironment sequesters adipose-derived stem cells in a murine model of reconstructive surgery in the setting of concurrent distant malignancy. Plast. Reconstr. Surg. 127(4):14671477.

Avogaro A., Albiero M., Menegazzo L., Kreutzenberg S. \& Fadini G.P. 2011. Endothelial dysfunction in diabetes: the role of reparatory mechanisms. Diabetes Care 34(2):285-290.

Badillo A.T., Redden R.A., Zhang L., Doolin E.J. \& Liechty K.W. 2007. Treatment of diabetic wounds with fetal murine mesenchymal stromal cells enhances wound closure. Cell Tissue Res. 329(2):301-311.

Balbino C.A., Pereira L.M. \& Curi R. 2005. Mecanismos envolvidos na cicatrização. Revta Bras. Ciênc. Farm. 41(1):27-51. 
Barbosa A.L.T., Del Carlo P.J., Gomes H.C., Oliveira A.C., Monteiro B.S. \& Del Carlo B.N. 2008. Plasma rico em plaquetas para reparação de falhas ósseas em cães. Ciência Rural 38(5):1335-1340.

Bjornson C.R., Rietze R.L., Reynolds B., Magli M.C. \& Vescovi A.L. 1999. Turning brain into blood: a hematopoietic fate adopted by adult neural stem cells in vivo. Science 283(5401):534-537.

Boyle J.P., Honeycutt A.A., Narayan K.M.V., Hoerger T.J., Geiss L.S., Chen H. \& Thompson T.J. 2001. Projection of diabetes burden through 2050. Diabetes Care 24(11):1936-1940.

Buschard K. 2011. What causes type 1 diabetes? lessons from animal models. APMIS 119(Suppl. 132):1-19.

Carvalho P.T.C., Mazzer N., Reis F.A., Belchior A.C.G. \& Silva I.S. 2006. Analysis of the influence of low-power HeNe laser on the healing of skin wounds in diabetic and non-diabetic rats. Acta Cir. Bras. 21(3):177-183.

Chiari L., Niciporciukas M.C., Campos J.V.M. \& Gesztesi J. 1988. Avaliação de curativos adesivos sobre ferimentos incisionais experimentais. Anais Bras. Dermatol. 63(2):103-106.

Choi J.B., Uchino H., Azuma K., Iwashita N., Tanaka Y., Mochizuki H., Migita M., Shimada T., Kawamori R. \& Watada H. 2003. Little evidence of transdifferentiation of bone marrow-derived stem cells into pancreatic beta cells. Diabetologia 46(10):1366-1374.

Del Carlo R.J., Monteiro B.S. \& Argôlo Neto N.M. 2009. Células-tronco e fatores de crescimento na reparação tecidual. Ciênc. Vet. Tróp. 11(1):167169.

Delfino V.D.A., Figueiredo J.F., Matsuo T., Favero M.E., Matni A.M. \& Mocelin A.J. 2002. Diabetes mellitus induzida por estreptozootocina: comparação em longo prazo entre duas vias de administração. J. Bras. Nefrol. 24(1):31-36.

Derossi R., Coelho A.C.A.O., Mello G.S., Frazílio F.O., Leal C.R.B., Facco G.G. \& Brum K.B. 2009. Efeitos do gel de plasma rico em plaquetas na cicatrização de feridas cirúrgicas na pele de cavalos. Acta Cir. Bras. 24(4):276281.

Falanga V., Iwamoto S., Chartier M., Yufit T., Butmarc J., Kouttab N., Shrayer D. \& Carson P. 2007. Autologous bone marrow-derived cultured mesenchymal stem cells delivered in a fibrin spray accelerate healing in murine and human cutaneous wounds. Tissue Eng. 13(6):1299-1312.

Frykberg R.G., Driver V.R., Carman D., Lucero B., Borris-hale C., Fylling C.P., Rappl L.M. \& Clausen P.A. 2010. Chronic wounds treated with a physiologically relevant concentration of platelet-rich plasma gel: a prospective case series. Ostomy. Wound Manag. 56(6):36-44.

Grossi S.A.A. 1998. Prevenção de úlceras nos membros inferiores em pacientes com diabetes mellitus. Revta Esc. Enferm. USP 32(4):377-39.

Herzog E.L., Chai L. \& Krause D.S. 2003. Plasticity of marrow-derived stem cells. Blood 102(10):3483-3493.

Hughson A., Bromberg I., Johnson B., Quataert S., Jospe N. \& Fowell D.J. 2011. Uncoupling of proliferation and cytokines from suppression within the cd4+cd25+foxp3+t-cell compartment in the 1st year of human type 1 diabetes. Diabetes 60(8):2125-2133.

Inoue H., Murakami T., Ajiki T., Hara M., Hoshino Y. \& Kobayashi E. 2008. Bioimaging assessment and effect of skin wound healing using bone-marrow-derived mesenchymal stromal cells with the artificial dermis in diabetic rats. J. Biomed. Opt. 13(6):36-46.

Jiang Z.Q., Liu H.Y., Zhang L.P., Wu Z.Q. \& Shang D.Z. 2011. Repair of calvarial defects in rabbits with platelet-rich plasma as the scaffold for car- rying bone marrow stromal cells. Oral Surg. Oral Med. Oral Pathol. Oral Radiol. Endod. 113(3):327- 333.

Kim C.H., Lee J.H., Won J.H. \& Cho M.K. 2011. Mesenchymal stem cells improve wound healing in vivo via early activation of matrix metalloproteinase- 9 and vascular endothelial growth factor. J. Korean Med. Sci. 26(6):726-733.

Kwon D.S., Gao X., Liu Y.B., Dulchavsky D.S., Danyluk A.L., Bansal M., Chopp M., McIntosh K., Arbab A.S., Dulchavsky S.A. \& Gautam S.C. 2008. Treatment with bone marrow-derived stromal cells accelerates wound healing in diabetic rats. Int. Wound J. 5(3):453-463.

Maharlooei M.K., Bagheri M., Solhjou Z., Jahromi B.M., Akrami M., Rohani L., Monabati A., Noorafshan A. \& Omrani G.R. 2011. Adipose tissue derived mesenchymal stem cell (ad-msc) promotes skin wound healing in diabetic rats. Diabetes Res. Clin. Pract. 93(2):228-234.

Mandelbaum S.H., Santis E.P. \& Mandelbaum M.H. 2003. Cicatrização: conceitos atuais e recursos auxiliares. Parte I. Anais Bras. Dermatol. 78(4): 393-410.

Mehta S.K., Breitbart E.A., Berberian W.S., Liporace F.A. \& Lin S.S. 2010. Bone and wound healing in the diabetic patient. Foot Ankle Clin. 15(3): 411-437.

Meirelles L.S., Chagastelles P.C. \& Nardi N.B. 2006. Mesenchymal stem cells reside in virtually all post-natal organs and tissues. J. Cell Sci. 119(11):2204-2213.

Nardi N.B. \& Meirelles L.S. 2006. Mesenchymal stem cells: isolation, in vitro expansion and characterization. Handb. Exp. Pharmacol. 174:249282.

Nauta A.J. \& Fibbe W.E. 2007. Immunomodulatory properties of mesenchymal stroma cells. Blood 110(10):3499- 3506.

Saad S.H., Elshahat A., Elsherbiny K., Massoud K. \& Safe I. 2011. Platelet-rich plasma versus platelet-poor plasma in the management of chronic diabetic foot ulcers: a comparative study. Int. Wound J. 8(3): 307-312.

Shi C., Zhu Y., Su Y. \& Cheng T. 2006. Stem cells and their applications in skin cell therapy. Trends Biotechnol. 24(1):48-52.

Spadella C.T., Macedo C.S., Machado J.L.M., Schellini A.S. \& Padovanni C.R. 2005. Estudo comparativo entre cinco diferentes tratamentos sobre as alterações clínicas e laboratoriais do rato diabético induzido pela aloxana. Acta Cir. Bras. 20(1):46-54.

Tark K., Hong J., Kim Y., Hahn S., Lee W. \& Lew D. 2010. Effects of human cord blood mesenchymal stem cells on cutaneous wound healing in leprdb mice. Transpl. Surg. Res. 65(6):565-572.

Touvra A.M., Volaklis K.A., Spassis A.T., Zois C.E., Douda H.D., Kotsa K. \& Tokmakidis S.P. 2011. Combined strength and aerobic training increases transforming growth factor- $\beta 1$ in patients with type 2 diabetes. Hormones 10(2):125-30.

Triola M.F. 1999. Introdução à Estatística. 7aㅡ ed. LTC, Rio de Janeiro. 656p.

Vendramim F.S., Franco D., Shamall R.F. \& Franco T.R. 2010. Utilização do plasma rico em plaquetas autólogo em enxertos cutâneos em coelhos. Revta Col. Bras. Cir. 25(1):4-10.

Verfaillie C.M. 2002. Adult stem cells: assessing the case for pluripotency. Trends Cell Biol. 12(11):502-508.

Volpato G.T., Damasceno D.C., Campos K.E., Rocha R., Rudge M.V.C. \& Calderon I.M.P. 2006. Avaliação do efeito do exercício físico no metabolismo de ratas diabéticas prenhes. Revta Bras. Med. Esporte 12(5):229-233. 